\title{
一特集 脈管造影·手技と合併症
}

脳 血管 造 影

神保実*

はじめに

脳神経外科領域に括ける血管撮影は, 脳血管 撮影と脊䯣血管撮影に分けられるが，ここでは 脳血管撮影について述べる。脳血管撮影には, 頸動脈撮影，椎骨動脈撮影などの他に静脈洞撮 影, 眼静脈撮影などがあるが，すでに確立され た検査技術であり，これに関する成書も多い。 以下，当科で行なっている検査法を中心に述べ たい，当科といえども，特に変った血管撮影法 を行なっているわけではない，強いて特徵的な ことをあげるなら, 検査件数が多いことである， 週平均 40 件の脳血管撮影が行なわれる。限られ た時間内にこれらを消化しなければならないの であるから，それなりの工夫が必要である。

\section{I. 一般的注意}

脳血管撮影の適応についてであるが, 脳の器 質的病変が疑われる場合の全てがその適応とな る. 頭部外傷, 脳血管障害, 脳腫瘍などであ る.むしろ脳血管撮影の禁忌を数える方が困難 である。ヨード過敏症，重症腎不全などが絶対 的禁忌となる。年令は余り問題にならない，老 年者でも必要とあらば敢て検査しなければなら ない，疾患の重篤度も同様である，重篤な状態 であればある程，可及的早急に頭蓋内の病態を 確認しなければならないからである。

前処置としてはアトロピン $20.5 \mathrm{mg}$ (成人) を検査前 30 分前に筋注する。また，検查前 1 回

* 東京女子医科大学脳神経センター
の食事をとめる。 ヨード過敏症の有無を確かめ ることは不可欠である。検査前に造影剂 $1 \mathrm{cc}$ を 静注して反応をみる．アナフィラキシーショッ クに対しては $1 \mathrm{cc}$ といえども危険なのである が，現在のところ他に適当な検査法がない，

麻酔は，局所麻酔で十分である，局所麻酔の ときは，前処置としてアトロピンの他に $10 \%$ フ ェノバール $1 \mathrm{~A}$ またはジアゼパム $10 \mathrm{mg}$ を筋注 しておくとよい，われわれは，最近 NLA の変 法として, pentazocin 15〜30 mg, diasepam 10 〜20 mg（成人）を静注している。この際，局 所麻酔の必要はない，乳幼児の場合はケタラー ル1〜2 mg/kg を用いる。

脳血管撮影は，全身状態の悪い患者にも行な い得るのであるが，この際には十分な救急処置 の用意が必要である。送管，気管切開などはた だちに施行できるよら準備されていなければな らない，患者によってはあらかじめ点滴によっ て静脈を確保してから検査を行なら場合もあ る.

\section{II. 頸動脈撮影}

患者を背臥位にし，肩あてを入れるか，頭部 を多少拈とすことにより頸部を伸展位にする。 総頸動脈を穿刺するのであるが，下顎角と頸窩 を結ぶ線の中点で，胸鎖乳突筋の前縁部を狙ら とよい，穿刺部位をきめたら，該部を消毒し， 滅菌ゴム手袋をはめる。

穿刺針としては，われわれは disposable なタ イガー血管撮影セットを用いている（図 1 D). これは針にチューブが接続されて扣り，チュー ブにはこれを締める括栓がついている。このセ 




図 1

ットに注射器を接続しチューブを生理食塩水で 満たした状態にして使用する。成人の場合, 使 用する針の太さは 18〜19 gauge である。乳幼児 の場合には，21〜23 gauge の HAKKO ェラスタ 一を使用することが多い(図 $1 \mathrm{C}$ ). 穿刺針の 固定が容易であるからである，穿刺後これにコ ネクターチューブを接続する（図 $1 \mathrm{E}$ ）。

穿刺方法は型のごとくである. 左示指, 中指 を用いて総頸動脈の膊動を十分確認する。そ己 て多少正中側飞押すようにすると総頸動脈は固 定される，次汇両指の間で穿刺針を刺入する。 穿刺の角度は皮膚面に対して $60^{\circ}$ 程で，針の切 りロは上に向ける。刺入していき針先が動脈壁 に達すると，搏動を針を通して手に感じる場合 があるが，必ずしも常にではない，針先が頸動 脈壁に達する程度に深く刺入したと思ったら， ここで一挙に頸動脈を刺通する，頸動脈を串刺 しにするのである，次に穿刺針を少しねかすよ らにして，ゆっくり針を抜いてくる，針先が動 脈腔内に入るとチューブ内に血液が逆流してく る．針先が血管内に入る際，針先が頸動脈の後 壁をプッンとはじく感触を手に感ずる場合が多 い．血液の逆流は十分に確かめなければならな い. 18 gauge の針を用いた場合，逆流した血液 によって，垂直に立てた $20 \mathrm{cc}$ 注射器の内筒が
容易に持ちあげられる，逆流が不十分な場合は 針先の一部が血管壁に残っているのである。こ のような状態で造影剂を注入すると，血管外注 入または血管壁内注入の危険がある。エラスタ 一やCournand 針を用いた場合は，血液の逆流 を確認したら針先を血管腔内に押しこも．これ によって抜ける心配がなくなる，先の鋭利の針 の場合も多少押しこむようにした方がよいので あるが，先が鋭利であるため再び 血管壁を刺 し，血液の逆流が不十分になる場合がある．血 液の逆流を確認した位置で穿刺針を皮膚に固定 してよい，固定は絆創膏で軽く皮膚に固定する だけでよい，場合によっては，針の下に小さい ガーゼの枕をかませる。

穿刺は, 第 1 回目の穿刺がもっとも成功率が 高いと心得るべきである. 2 回，3回と穿刺を 繰返すと頸動脈の攣縮を惹起し穿刺しにくくな る。一旦，血管腔に入った針がなんかの拍子に 抜けた場合，あわてて穿刺をやり直してはいけ ない，動脈壁の穿刺孔から出血し, 動脈周囲に 血腫をつくるため頸動脈の膊動を触れにくくな り穿刺が困難になる。このような場合には 5 〜 6 分間頸動脈を圧迫して止血をまつとよい. 穿刺が終ったら，造影剤を注入し，レントゲ ン撮影を行なう。造影剂としてはウログラフィ 


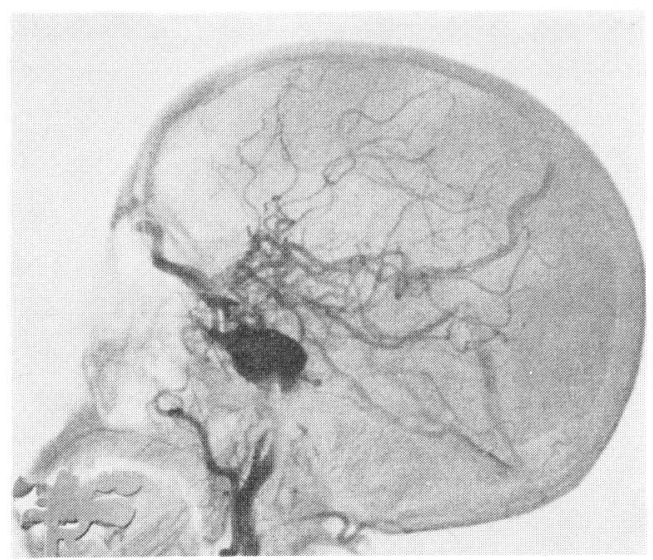

図 2 项動脈海綿静脈洞霓, subtraction 側面像

ン，コンレイ，コンラキシンLなどの Tri-Jod 系の造影剂が普及している。低濃度の造影剂を 使用すべきで，われわれは64.9\%コンラキシ ンしをよ用いる。注入方法は注射器を接続し て手押しでもよいが，自動注入装置が好るし い. 連続撮影を行ならため検者の被曝量も少な くないからである。われわれは，Elema-Schönander の Cisal II 型自動注入装置を用いてい る. 成人頸動脈撮影の場 合, 注入量は $10 \mathrm{cc}$, 注入王は 3 気圧で，注入を終るのに 0.8 秒を要 する，小児の場合，穿刺針が 21〜23 gauge と細 くなるので，注入圧をそれ程下げることはでき ないのであるが，多少低目で 2.5 気在程度にし ている。造影剂注入量は生後 1 カ月から 3 歳ま では $3 \mathrm{cc} \sim 6 \mathrm{cc}$ である。

レントゲン撮影装置としては Elema-Schönander の脑血管撮影用 同時 2 方向 連続撮影装置 を用いている. Film Changer は AOT 型であ る. 撮影方向は前後, 側方向の 2 万向をむって standard としている。前後方向は, 通常管球を orbitomeatal line に対して 20〜30 傾けた半軸 方向撮影を行なっている。撮影条件は，成人 頸動脈撮影前後像では $85 \mathrm{KVp}, 400 \mathrm{~mA}, 0.08$ $\mathrm{sec}$ ，側面像では $75 \mathrm{KVp}, 400 \mathrm{~mA}, 0.08 \mathrm{sec}$, 乳幼児の場合は, 前後像 $70 \mathrm{KVp}, 320 \mathrm{~mA}$, $0.06 \mathrm{sec}$ ，側面像 $65 \mathrm{KVp}, 320 \mathrm{~mA}, 0.06 \mathrm{sec}$ で ある. シーメンスの Diamond 増感紙を使用し ている、レントゲン線の曝射間かくは症例によ

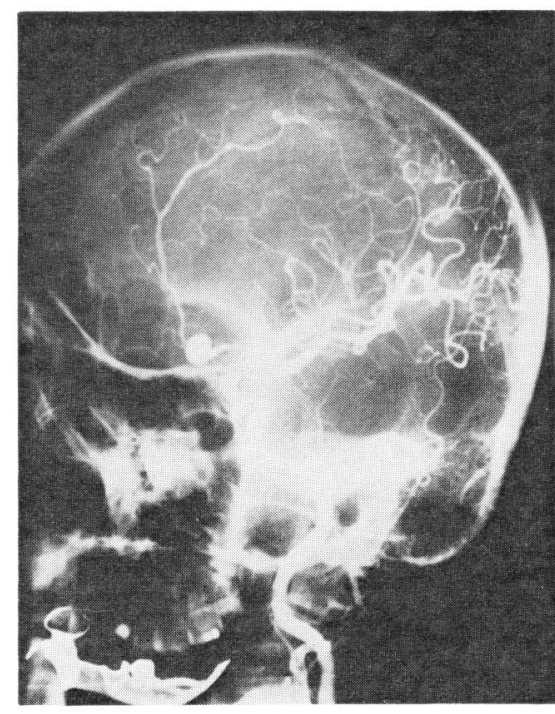

図 3 前交通動脈瘤, 斜位撮影( 穿刺側の反対 側に頭部を傾けている)

って異なるが，通常，成人の場合は 7 秒で，小 児（10歳以下）の場合は 5 秒で 8 回の曝射を行 なうようにセットする。動脈相は0.5秒間かく， 毛細管相，静脈相は $1 \sim 2$ 秒間かくである. 曝 射開始は，造影剂注入開始後 $0.3 \sim 0.5$ 秒（小児 $0.2 \sim 0.3$ 秒) である. suctraction 用に注入開始 と同時に 1 枚とることもある（図 2 ）.

通常の撮影方向は前後, 側方向であるが, 疾 患によっては特殊方向の撮影が必要である. 特 に脳動脈瘤の場合には, 動脈瘤頸部の形状を把 握するため種々の撮影方向が試みられる. 斜位 では前後方向の撮影に際し，頭部を左右いずれ かの方向に $10 \sim 20^{\circ}$ 傾活る（図 3 ）。斜位撮影は 前頭部の硬膜下血腫の確認のためにも有用であ る. 患者に頭蓋底撮影の頭位をとらせ，投射方 向が orbitomeatal line に直角になるように管 球をセットしたのが軸位である（図 4 ）。

特殊な撮影方法として断層脳血管撮影 9 , 立 体脳血管撮影 3 ，拡大脳血管撮影などがある。 これらの特殊撮影は, 頸動脈撮影に限らず他の 血管撮影にも適用されるのであるが，ここで簡 単に触れる。

血管撮影像は, 立体的に分布する脳血管の平 面投影図である。したがって血管相互の重なり 


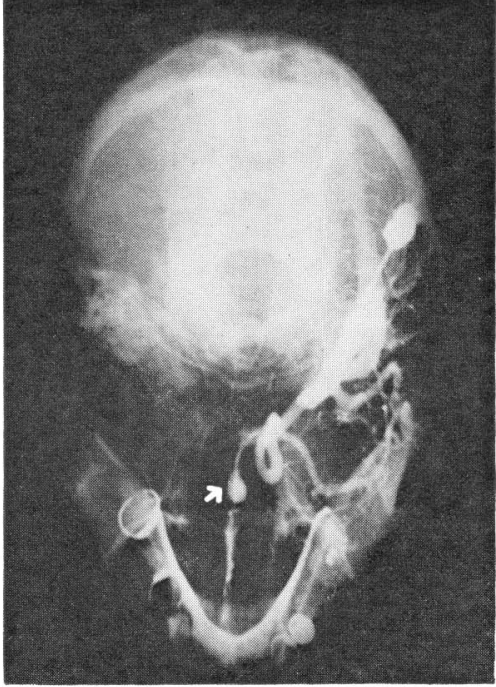

図 4 前交通動脈瘤軸位撮影

合いが特にくわしく検索したい部位の読影を困 難にする場合がある，例えば前交通動脈瘤のく わしい読影は，側面像では困難であることが多 い. 断層撮影は血管撮影中に断層撮影を行な い，特にこまかく観察したい部分のみを造影す る方法である，立体撮影では，管球を 10 数 $\mathrm{cm}$ 平行移動して血管撮影を 2 回行ない， 2 枚のフ ィルムを viewer にかけて立体的に観察する。 したがって造影剤の注入は 2 回行なう。撮影に 際してはりスホルムの置き方が大切である。㹡 大撮影は，血管像の一部を桩大撮影して精細比 観察する方法である。管球を頭部に接近させ， フィルムカセットを頭部から離せばいくらでも 拡大された像が得られるわけであるが，相対的 位置関係には最適の条件がある。

以上のようにして，撮影が終了したら穿刺針 を抜去する，撮影を繰返すなど検査に時間を要 するときは途中適時生理食塩水でチューブを洗 浄する。へパリンは用いない，穿刺針を抜去し たあとは数分間該部を圧迫する。

その後穿刺部を消毒し，伴創膏でガーゼを多 少圧迫するように固定する。

\section{III. 椎骨動脈撮影}

椎骨動脈撮影法は，3つに分けられる１つ は直接椎骨動脈を穿刺し造影剂を注入する方法
である. 2 つは上腕動脈より逆行性に造影剂を 高圧注入する方法，3 つは大腿動脈，腋窩動脈 などより Seldinger 法によりカテーテルを誘導 乙椎骨動脈に造影剂を注入する方法である。

椎骨動脈を直接穿刺する方法は技術的に大変 難かしい，その成功率は70\%といわ机る。その 上, 頸腕神経㦑, 交感神経節の損傷, 䯣液腔内 注入などの危険があり現在では余り用いられな い. Seldinger 法は優れた方法であるが，検査 の準備，無菌操作などの面でいささか煩雑であ り，当科のように多数の症例を消化しなければ ならないところでは実際的でない。われわれが 用いている方法は，経皮的経上腕動脈性椎骨動 脈撮影法である。

前処置その他の一般的注意は頸動脈撮影々同 様である，患者を背臥位にし，上腕の内側二頭 筋溝で上腕動脈の搏動をもっともよく触れる部 分を消毒し，その周囲を滅菌布で覆う。

穿刺針としては，成人の場合は $20 \sim 30 \mathrm{~cm}$ の $\mathrm{HAKKO}$ エラスターを用いる（18 gauge，図 $1 \mathrm{~A}$ ). 小児の場合は通常の (短かい) エラス ター（21〜23 gauge）である。穿刺方法は頸動 脈の場合と同じである。減菌手袋をはめた左手 の示指中指で上腕動脈の膊動を確認し，両指の 間で穿刺部位の皮虐に小切開を加えたのちエラ スターで穿刺する，上腕動脈を串刺しにするよ うに穿刺する（図 5 ），次に内筒（針）を数 $\mathrm{cm}$ 拔いた状態でェラスターを除々に引き奴いてく る。外筒が血管腔内にはいると血液が逆流して くる，次に内筒を抜さながら外筒を血管腔内に 押し進める（図 6 ）。外筒が 正確に 血管腔内に ある時は，拔いた内筒を追うようにして血液が 逆流してくる，内筒を抜き終ったらすばやく外 筒に生理食塩水を満たしたコネクターチューブ を接続する（図 7 ). 20〜30 cm のエラスターを 用いると，成人の場合先喘部は腋窩附近に到達 する。

造影剂の注入量は成人 $25 \sim 30 \mathrm{cc}$ ，小児 10 $15 \mathrm{cc}$ である。注入压は成人・小児ともに 4 気 压である，注入に要する時間は成人 1.4 秒，小 児 1 秒であり, 最初の曝射を, 注入開始後, 成 人 1 秒，小児 0.5 秒で行なら。その他の諸条件 


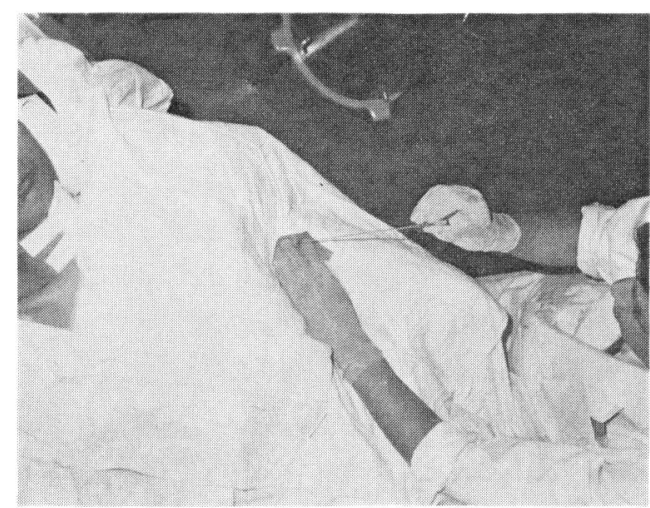

図 5

は頸動脈撮影の場合と同じである。ただし頸部 の椎骨動脈を造影する場合には管球の位置を変 えなければならない。

左側の上腕動脈を利用すれば左椎骨動脈と脳 底動脈が造影される. 右側の場合は, 右頸動脈 系，右椎骨動脈，脳底動脈などが同時に造影さ れてくる.

\section{IV. 撰択的外頸動脈撮影}

頭皮の病変のみならず，髄膜腫や脳動静脈奇 形の診断に撰択的外頸動脈撮影は重要である. 脳動静脈奇形では，外頸動脈から feed されて いる病巣が少なからずある。

撰択的外頸動脈造影法としては種々の手技が ある. 浅側頭動脈を露出し, 逆行性にカテーテ ルを外頸動脈起始部まで誘導し，造影剂を注入 することができる. Seldinger 法によりカテー テルを外頸動脈まで誘導することもできる，外 頸動脈を経皮的に直接穿刺することは困難であ る、総頸動脈穿刺の際，頸部を反対側にひねっ て穿刺針を押し進めると外頸動脈にはいり易い といわれる。しかし成功率は30〜40\%である。 外頸動脈撮影専用の穿刺針が開発されている (図 1 B $)^{22}$. 19 gauge, $13 \mathrm{~cm}$ のテフロン針であ るが，先端部 $1.5 \mathrm{~cm}$ が $45^{\circ}$ 屈曲している。これ を内筒針によりまっすぐな状態にして総頸動脈 を穿刺する、次に内筒を抜去しテフロン針を屈 曲した状態に戻してから先端部を外頸動脈に誘 導する。テレビの透視下に誘導すればさらに容 易である.

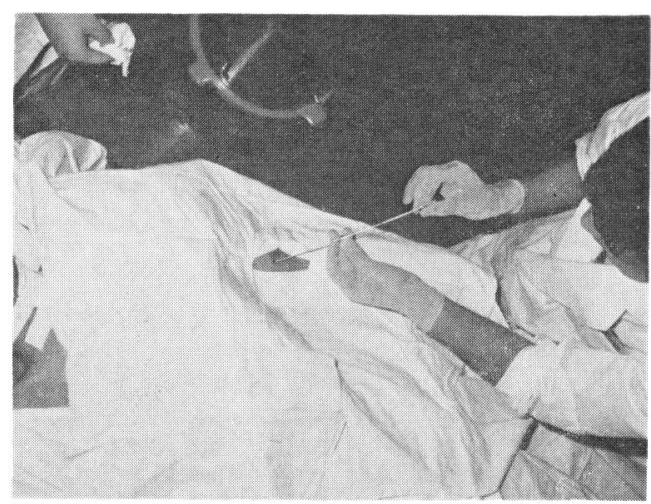

図 6

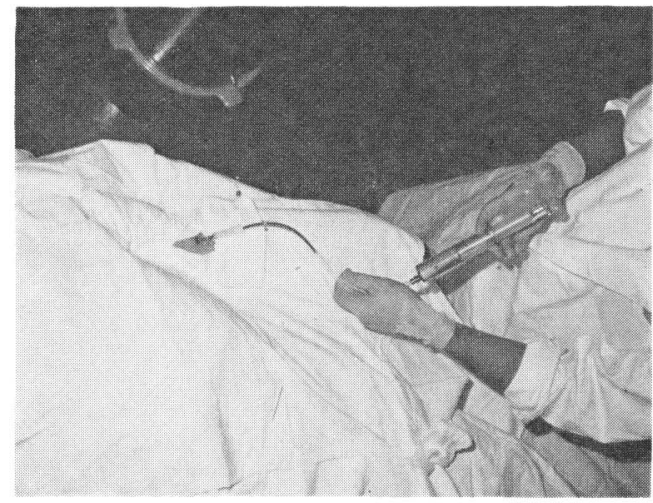

図 7

\section{V. 静脈撮影}

連続血管撮影でも静脈系を造影することは可 能であるが，静脈撮影では直接静脈系に造影剤 を注入する。静脈洞撮影 (sinusography) と眼窝 静脈撮影 (orbital phlebography) とがある。静 脈洞撮影には，頭蓋正中部に穿頭し上矢状洞を 直接穿刺し造影剂を注入する方法と，内頸静脈 より逆行性に造影剂を注入する方法とがある。 前者では上矢状洞, 横静脈洞, $\mathrm{S}$ 状静脈洞など が造影される，傍矢状髄膜腫で上矢状洞の閉塞 状況を検するのに便利である，後者では，乳様 突起部で内頸静脈を穿刺し，カテーテルを頸静 脈球まで誘導して造影剤を注入する。

$\mathrm{S}$ 状静脈洞, 横静脈洞, 海線静脈洞などが造 影される。大腿静脈よりカテーテルを内頸静脈 まで誘導する方法もある ${ }^{8)}$.

眼窩静脈撮影は眼窩腫瘍のみならず，下垂体 
およびその近傍の腫瘍の診断に有用である5). 穿刺部位としては, 眼角静脈か, 前頭静脈が壳 らばれる。これらの静脈の経皮的穿刺を容易に するために静脈を怒張させる，通常, 頸部を圧 迫したり，頭部を低位に执いたりする。 Thiopental natrium で静脈麻酔すると静脈は拡張す る7). 18〜21 gauge の穿刺針を用い，成人の場 合 $10 \mathrm{cc}$ 前後の造影剂を迅速に注入して撮影す る. 造影剂が顔面の静脈に逃げないように顔面 周囲を用手的または簡単な装具で圧迫する。眼 静脈, 海綿静脈洞などが造影される. 撮影方向 としては逆 Water 撮影, 頭 蓋底撮影などの診 断的価値が高い.

\section{VI. 合併症}

われわれの印象では脳血管撮影はきわめて安 全な検查である。しかし合併症がないわけでは ない. 合併症は局所的なもの, 全身反応性のも の, 脳症状を呈するものなどに分けられる。合 併症の発生率についても種々報告されている が，それらの発生率を正しく評価することは困 難である。 どの程度の症状をもって合併症とす るかによって発生率が変ってくるからである。 また脳血管撮影による死亡率にも問題がある. 死亡が問題になるのは，大部分重症例について である，その症例が検査後死亡したとしても， その原因が検査自体にあるのか，疾病の必然的 経過によるものかについては判断に苦しむ場合 が多い. アナフィラキシーのショックで死亡す ることは，実際に存在するのかも知れないが， きわめてまれであろう，以上のことを念頭に打 いて二，三の統計を引用してみる．Perret 拉よ びNishioka4) のクモ膜下出血患者 5, 484 名につ いての集計では, 頸動脈撮影, 椎骨動脈撮影を 含めて合併症の発生率は $7.6 \%$ であり, 致命的 合併症の 発生率は $0.82 \%$ である Feild らは 1,000 名の患者に対して 経上腕動脈性椎骨動脈 撮影1,202回, 頸動脈撮影1,009回行なった. 合 併症の発生した症例は67例で52例が mild (一過 性の運動障害, 一過性の radial pulse の消失な ぞ）であり，15例が severe（脳幹症状など）で あった。 したがって合併症の発生率は $6.7 \%$ で
ある.これを穿刺動脈数についてみると3.07\% となる. 経上腕動脈椎骨動脈撮影のみについて みると，検查数あたり $3.99 \%$, mild $3.32 \%$, severe $0.60 \%$ となる。 また死亡率は $0.21 \%$ であ る. Taveras 抽よび Wood の経験によれば, 脳 血管撮影によって脳症状を呈する合併症の発生 率は $2 \%$ であるとい ${ }^{6)}$. 以上のように発生率 は報告によってまちまちであるが，われわれ は, 臨床的に問題になる合併症の発生率は $2 \%$ 以下, 死亡を含めた重篤な合併症の発生率は $0.6 \sim 0.8 \%$ 程度でないかと考えている. 当然の ことながら, 検査時間がのび, 造影剂の使用量 が増せば，合併症発生の危険も増してくる。乙 たがって穿刺技術の習熟は大切であり, 同時二 方向撮影装置は造影剤の使用量を減らすために も有益である，以下合併症の内容と対策につい て簡単にふれたい。

\section{1. 局所的合併症}

頸動脈撮影の場合, よくみられる合併症は穿 刺部位の血腫である。通常, 温湿布などの保存 的処置で十分であるが，大きい血腫のために気 管が圧迫されて呼吸困難をきたし気管切開を必 要とすることもある。造影剤の血管外注入, 血 管壁内注入の場合には患者は穿刺部位から歯に かけて激しい痛みを訴える。血管壁内注入では 頸動脈の閉塞をきたすことがある。そのほか, 頸腕神経叢の損傷, Horner 症候群がみられる ことがある。

上腕動脈穿刺の場合, もっとも多い合併症は radial pulse の消失である。一過性の場合も永 久性の場合もあるが，末梢の循環障害を示す場 合はむしろまれである。正中神経麻痺がみられ ることがある，血管外注入の場合に多い。

\section{2. 全身的合併症}

造影剂注入時に, 顔面紅 潮, 悪心嘔 吐, 頻 脈, 徐脈, 血圧低下, 呼吸不整などがみられる ことがある。多くは一過性である、ヨード過敏 症の有無は検査前に是非確かめておかねばなら ない.アレルギー体質の患者では薨麻疹, 眼瞼 浮腫などがみられる場合がある。抗ヒスタミン 剂の投与で軽快する，1回目の検査でョード過 敏反応を呈した患者が 2 回目の検査で同様の反 
応を示すとは限らない，微量のヨードでも誘発 されるであろらアナフィラキシーショックはわ れわれの経験ではない。

\section{3. 脳合併症}

てんかん, 意識混濁, 片麻痺, 失語症などで ある．多くは一過性である，動脈硬化の強い患 者で穿刺部位のアテロームがとんで脳梗塞症状 を呈することもあるが，多くは造影剂の影響で ある，健康人の場合，造影剤が血脳関門を侵す ことはないが，すでに脳に器質的病変があって 血脳関門も障害されている場合，造影剂の血脳 関門に与学る影響は少なくない，比較的軽い症 状で入院してきた脳腫瘍患者に対して検査を繰 返しているらちに症状が悪化してくる場合があ る. 脳血管撮影に際しては高濃度の造影剂を大 量に使用してはならない，造影剂が脳を通過す る際, 一過性の脳の hypoxia が脳障害の原因と なるからである。このような場合の処置として は, 安静, 酸素吸入, 血圧の管理, ステロイド の投与などである。星状神経節ブロックが効果 的な場合もある. 脳腫瘍の場合にはなるべく早 く手術にもっていくことが望ましい.

\section{おわりに}

以上，脳血管撮影の手技について，われわれ の経験を中心に述べた。脳血管撮影の手技のす べてを紹介したわけではないが，なんらかのお 役に立てば幸せである。

\section{文献}

1) Feild, J.R., Lee, L. \& McBurney, R.F.,: Complications of 1000 brachical arteriograms. J. Neurosurg., 36; 324-332, 1972.

2）福島孝徳, 間中信也, 平川公義: 選択的外頸 （内频）動脈撮影, 一一新しい needle-cathter assembly そついて—. 脳と神経, 25; 218222, 1973.

3）松井孝喜, 天野恵市, 喜多村孝一, 佐野圭司, 大島太市：Microstereo-angiography，脳と神経， 25; 307-313, 1973.

4) Perret, G. \& Nishioka, H.,: Cerebral angiography, An Analysis of the diagnostic value and complications of carotid and vertebral angiography in 5484 patients. J. Neurosurg., 25; 98-114, 1966.

5) 末吉 俊：眼静脈・海綿静脈洞撮影, 特にトル コ鞍打よびその近傍病変に対する䛦断的価值に ついて。脳と神経, 25；573-584, 1973.

6) Taveras, J.M. \& Wood, E.H.,: Diagnostic Neuroradiology. Williams \& Wilkins Co., Baltimore, pp. 1485-1490, 1964.

7）高久 晃, 鈴木二郎, 児玉南海雄：眼窩掞よび 頭蓋底静脈撮影法。脳々神 経, $20 ； 621-627$, 1968.

8）高橋睦正, 田中 誠, 奥寺利男: 上眼静脈, 海 綿静脈洞造影法——特に大腿静脈カテーテルに よる新しい造影法について——. 脳と神経, 23; 1467-1476, 1971.

9) 戸谷重雄, 中西 亨, 村瀬活郎: 断層脳血管写, 脳と神経。 23；1439-1445，1971.

\section{Hippocrates books}

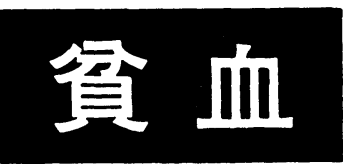

東邦大学名誉教授

森田久男著
血液研究 40 年の著者が語る貧血のすべて!! 一主要目次 -

貧血とは・貧血の原因・負血の分類・急性の出血・低色性貧血・鉄欠乏性 貧血に特徽的な症状・日本人の貧血傾向・インドネシア・妊婦の霓血・悪

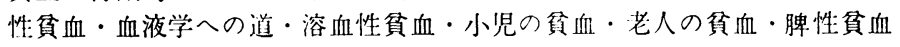
- 脾性発育障害 - 地方病騷動 - 骨硬化症 - 骨蹃癌症 - 急性白血病の貧血・ 純粋な再生不能生實血・再生不能性筫血

口新書判 200頁 定 価1,000円（平80）東京医学社刊 